\title{
'Abdīšō' of Gazarta, the first literate of the Chaldean Church: Poems dedicated to the Popes of Rome
}

\section{A. D. Pritula}

State Hermitage Museum, 34, Dvortsovaya nab., St. Petersburg, 190000, Russian Federation

For citation: Pritula A. D. 'Abdī̌s̄' of Gazarta, the first literate of the Chaldean Church: Poems dedicated to the Popes of Rome. Vestnik of Saint Petersburg University. Asian and African Studies, 2018, vol. 10, issue 3, pp. 374-391. https://doi.org/10.21638/spbu13.2018.307

The paper discusses Syriac verse texts from the Ottoman period which are connected with the history of the Chaldean (East Syriac Uniate) Church. They were composed by 'Adbǐšó of Gazarta, the second patriarch of the new Church (1555-1570), an outstanding literate, whose legacy has been significantly neglected by researchers. The pieces discussed in the present paper typify their very early samples epitomizing the beginning of this literary tradition that was connected with the name of 'Adbiššc of Gazarta. They were devoted to the Popes of Rome, with whom the young Chaldean Church had intensive contacts and whose supremacy it was in the process of acknowledging. Until recently, scholars have lacked access to most of the numerous textual corpora of this Church; as a result, research on these manuscripts had been confined to their catalogue descriptions, printed in the early- $20^{\text {th }}$ century. Although they have never been an object of detailed study so far, the short pieces discussed here, composed on various occasions, contain important evidence for both the history of Syriac literature and the history of the Christian Churches in this region. The names mentioned in the poems can be easily identified, which would serve to date the texts to certain periods of 'Adbiššc's Church career. The present paper is the first attempt of a detailed study and a critical edition of his poems dedicated to the Roman Catholic Popes.

Keywords: Syriac poetry, Chaldean Church, Christian communities in the Ottoman Empire, odes to Popes, manuscript transmission.

\section{Introduction}

The term Chaldean, originally meaning the population of Mesopotamia, was then applied by Europeans to East Syriac communities in general, communities whose centre was located in this region. It is more usual however to use it to differentiate East Syriac Uniate Church from the Church of the East (the so-called Nestorian). In fact, its official name is Chaldean Patriarchate of Babylon, and the main See is presently in Baghdad.

Until recently, scholars have lacked access to most of the numerous textual corpora of the Chaldeans; as a result, research about these manuscripts has been confined to descriptions printed in the early- $20^{\text {th }}$ century catalogues. Two fundamental works have recently changed this trend toward studying Church history of the Ottoman period in its relation to the East Syriac corpora of manuscripts. The first is a detailed study by David

() Санкт-Петербургский государственный университет, 2018 
Wilmshurst of the ecclesiastical organization of East Syrian Churches, extending from the early $14^{\text {th }}$ century till World War I [1]. The author uses colophons, in addition to published and even unpublished catalogues to survey the historical developments during those five centuries, developments that exerted a dramatic impact on Christian communities. Wilmshurst accumulated an abundance of information on thousands of manuscripts from most of the known collections.

The second principal publication is a recently released book by Heleen Murre-van den Berg on Syriac scribes and scriptures in the Eastern provinces of Ottoman Empire, in other words, on the development of the East Syriac tradition [2]. Unlike Wilmshurst, Murre-van den Berg focuses on textual transmission, genre development, and the sociohistorical role of scribes in literary life. Her monograph includes comprehensive accounts of the texts created in these literary circles as they appear in the principal collections described by earlier catalogues.

Owing to the digital work and re-cataloguing conducted by the HMML (Hill Museum and Manuscript Library, Minnesota) over the last 14 years, the scholarly community has obtained access to thousands of manuscripts belonging to this tradition. With this new access to manuscripts, scholars can now define the circulation and distribution of certain texts within the mainstream Chaldean Church tradition. Their digital preservation has become increasingly important because of their prolonged history of destruction starting in the early $20^{\text {th }}$ century and continuing now because of unrest in the Near East.

\section{1.'Abdīshō' of Gazarta, the second patriarch (1555-1570) of the Chaldean Church and his poetic legacy}

The Uniate East Syriac literary tradition starts with the name of 'Adbiššc' of Gazarta, the Church's second patriarch (1555-1570)1, first poet, and writer of numerous liturgical and non-liturgical poems, including descriptions of travels to Rome in a lengthy versified text. Dozens of these texts are epigrams addressed to the author's contemporaries. Most of his poems - the majority still unstudied - can be found in manuscripts now available through the digital copies made from numerous Oriental manuscript collections.

Practically nothing is known about 'Adbīšō's life before his Church career. He was ordained Metropolitan of Gazarta by the first Chaldean Patriarch Yōḥannān Sūlāqā in 1553. After the death of the latter, in 1555, 'Adbīšō was elected the second Patriarch by the five Chaldean bishops, but left for Rome to obtain confirmation of his title only in 1562, which was eventually received from Pope Pius IV. 'Adbīšō' was not present at the famous Council of Trent of 1562, since he had not reached Rome by that time, but his letters were read and discussed there [3, p. 412].

After returning to the Near East, he moved his residence to the monastery of Saint Jacob the Recluse near Seert, where he spent the rest of his life. The monastery remained the main centre of the first Chaldean Patriarchate for a long time [1, p.94-97].

One of the most detailed texts to discuss the early years of the Church is the poetic trilogy that 'Adbīšō' composed throughout his life. The previously unedited trilogy is copied in at least four manuscripts, three of which are in the Vatican library (Vat. Syr. 45, Vat.

1 The dating of his death is disputable, and I follow the one established by Wilmshurst [26, p.94] and Murre-van den Berg [4, p. 250-251]. 
Syr. 63 and Borg. Syr. 21) and one, in the Telkepe Chaldean Church collection (QACCT 00119). Its only publication in a 1931 French translation by Vosté lacks a critical apparatus and textual commentaries, as well as the original Syriac text [5].

The first and the lengthiest poem of the trilogy occupies almost thirty folios (see (QACCT 00119, fol. 1v-14v). It explains the reasons for the emergence of a new Church, protests against the abuses of the patriarch Šem'ōn VII bar Māmā and the election of a monk from the Alqosh monastery, Yōhannān Sūlāqā, as his alternative. An assembly of bishops in Mosul had gathered to elect the new hierarch. The poet then elaborately describes Yōhannān's travels to Rome, where the Pope ordained him as patriarch. The poem recounts his journey through all of the Ottoman Near East, including a pilgrimage to Jerusalem (to which much of his topographic data about holy places relates). From there he went to Rome, stopping every now and then on various islands in the Mediterranean. The tour also mentions an array of churches and monasteries that he visited. In the end, 'Adbīšó narrates the ceremony ordaining Yōhannān to the Patriarch of the Church of the East. The overall poem chronicles a year-long journey replete with precise details about time: it begins in November 1552 and lasts until November of the next year.

The second poem, much shorter than the first, narrates Yōhannān's return to the Near East and his eventual tragic fate (see QACCT 00119, fol. 15v-34v). This fate transpired when the patriarch of the traditional lineage, Šemōn VII bar Māmā, started plotting against the new Church and convinced the governor of the city of 'Amadiya to imprison him. Yōhannān spent four months in prison before Ottoman authorities killed him, hid his body in order to prevent his supporters from rebelling, and claimed he had escaped. A similar account appears in a short prose biography of Yōhannān written by Elìyā Asmar, metropolitan of Amid (Diyarbakir), one of the hierarchs, ordained by the murdered patriarch [5, p. 232-234].

The last and the shortest poem of the trilogy is called madrāš $\bar{a}$ (see QACCT 00119, fol. $34 \mathrm{v}-41 \mathrm{r}$ ), a genre that has a strophic form and a rather complex rhythmical structure. Madrāšās belong to liturgical texts and usually are performed to commemorate the dead. This particular version mourns the tragic death of the Patriarch, who is compared to early Christian martyrs.

Several $20^{\text {th }}$-century scholars have discussed 'Adbiššc of Gazarta's role in creating these poems. Anton Baumstark, who wrote an article on the Syriac descriptions of Rome, assumed that the text's numerous geographical details came from one of the Patriarch's companions for his Roman junket [6, S.333]. Vostés introduction to the French translation expressed doubts about this assumption, arguing that the lists of the people accompanying Yōḥannān Sūlāqā did not mention 'Adbīšōo [5, p. 195-196]. Therefore, one might conclude that 'Adbǐšó based his descriptions on geographical texts that he would have had at his disposal.

As mentioned earlier, this long, informative trilogy still requires a comprehensive study of its sources, including contemporary geographies, chronicles and archival materials. In fact, much of 'Adbī̌sōos corpus remains unstudied. In the present paper, I will discuss his shorter verse texts dedicated to different contemporary Popes. Most of these small pieces have not been studied or edited so far. 


\section{An ode in honour of Pope Paul IV}

Among a large number of various poems composed by 'Abdiššc of Gazarta, there is an ode devoted to a Pope. In all likelihood, this panegyric was sent to the Pope by the author long before his coming to Rome in 1562, namely in 1556 [3, p. 414; 7, p. 27-30]. It was Paul IV, who held the pontificate at that period, and to whom the poem was presented. The text has never been studied or critically published, which seems peculiar, given the historical and literary significance of the piece hailing from the very start of the Chaldean Church's literary tradition.

The present location of the original manuscript is unknown, and it can only be reconstructed according to a printed edition undertaken in 1617 in Rome (see fig. 1) [8, p. 62-67]. The edition itself is a collection of documents related to the 1614 visit by the Archdeacon Adam, emissary of Elìyā, Metropolitan of Amid (Diarbakir), to Pope Paul V and a confession of faith that served to establish union with the Catholic Church [3, p. 406]. Pietro Strozzi, a papal secretary in charge of these documents' publication, added some texts connected with earlier activities related to union with the Chaldeans, among them 'Abdišōo of Gazarta's poem [1, p. 417]. Apparently, this publication was based on the manuscript original kept in the papal chancery. Consequently, apart from being the only publication of this text, it is also the only reproduction of the original text we have. Likewise, it is also worth pointing out that there is no explicit reference in the book that the poem was addressed to Paul IV. The only time the name is mentioned it is just sobes 'Paul' (see below, text, verse 14), so that the readers might assume that the character in question is, indeed, Paul V, during whose pontificate the edition came out and to whom most of other texts concern. One can still question whether Strozzi included the reference to it intentionally.

Later, in the 1883, the poem was included in a printed anthology of Syriac Chaldean spiritual literature by Paul Bedjan called Manuel de piété [9, p. 599-601].

The poem was set in a rather unusual - in present terms - type, namely in West Syriac serto rather than in the Nestorian script normally used by the East Syriac tradition. This has apparently a very simple explanation: the contacts with the West Syrian communities started earlier and had been developing much more intensively. By that time West Syriac typography in Rome had a rather long history that had started already in the $16^{\text {th }}$ century and resulted in various books [see: 10,11], whereas printing in Nestorian script appeared much later (namely, in 1633) and was not widespread until the $19^{\text {th }}$ century $[10$, p. $213 ; 11$, p. 191].

The printed text of the poem has a rather interesting typesetting (see fig. 1): being divided into two columns, where the main text is grouped in the left one, and the letters of the acrostic in the right.

The only manuscript transmission of the text presently known is in BNF Syr. 434 (fol. 204r-205r) that represents a collection of different East Syriac religious texts of both liturgical and non-liturgical character, including apologetic, hagiographic and exegetic compositions [for a detailed description see: 12, p.178-183]. It has no dated colophon, but is datable to $18^{\text {th }}-19^{\text {th }}$ centuries, based on the palaeographic features, and thus presents a rather late stage of the textual transmission.

The print and manuscript versions have certain discrepancies. Apart from the fact

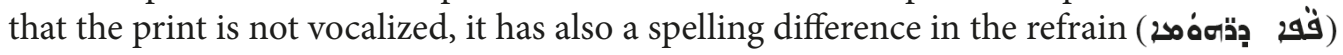




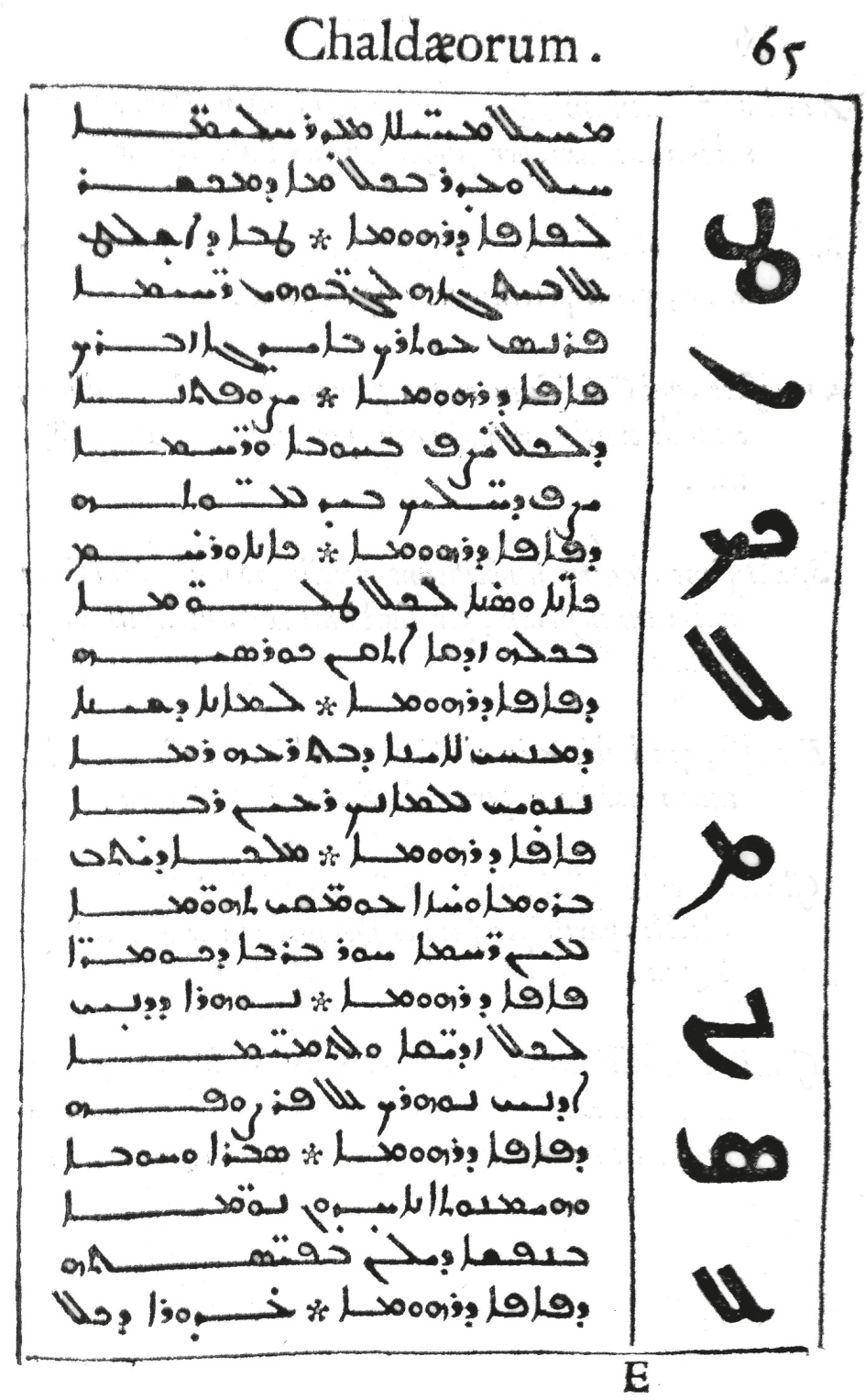

Fig. 1. An Ode in honour of Pope Paul IV by 'Adbī̌sō' of Gazarta. Strozzi P. Synodalia Chaldaeorvm. Rome, 1617 [8]

'Pope of Rome', where 'Pope' is written in scriptio plena (2920), and 'Rome' is spelled without the syame sign (250б). The former might have been an influence of Arabic or Garshuni $^{2}$, to be precise, as printing in Arabic already had a rather long tradition in the Roman Catholic typographies. The latter seems to be an adaptation to a usual (from the European point of view) spelling of Rome, whereas using the syame sign that normally marks the plural was obviously not comprehensible for the European publishers.

${ }^{2}$ I.e. a writing convention using Syriac script for texts in Arabic that has been popular among Christian communities in the Near East since 16th-17th centuries. 
In the manuscript, the name of the Pope to whom the poem was addressed is omitted in the line, and some space for it is left blank. In the printed version, on the contrary, the name of Paul (Sos) is clearly mentioned (see the Appendix, verse 14). As the text is well-known to have been written to be presented to Pope Paul V, one may assume his name read in the archetype that was in all likelihood, the poet's autograph itself. In the manuscript that represents a later copy, the name was skipped for some practical or political reasons.

The acrostic is lost in the manuscript, which is clearly a result of a scribal omission. It is well-known that an acrostic is present in the türgàmā poetic form, which is also found in the printed version that might be based on the autograph manuscript. A possible reason for such an omission might have been a non-strophic character of the text, as an acrostic, usually - apart from the tūrgāma form - marks stanzas. That is why I have followed the Synodalia book [8] in most discrepancies from the refrain that might be, as mentioned above, a modification undertaken specifically for printing.

The poetic form called tūrgāma ('explanation', 'commentary') was meant for liturgical purposes, to be used in the Church. It was chanted by a deacon at every Sunday liturgy before reading the Gospels and was to prepare the believers to it, offering emotional and theological context for the lection to be read thereafter [2, p.172-173]. The text under discussion undoubtedly belongs to this poetic form, as follows from its title in both print and the manuscript (see the Appendix).

Its most detailed version is contained in the Synodalia version:

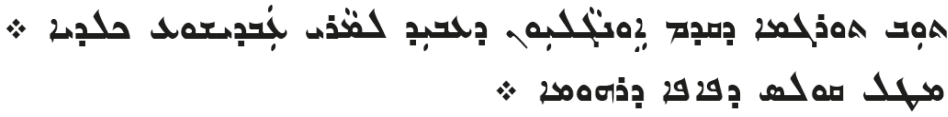

Then a tūrgàmā before the Gospels, composed by Mār 'Abdiššc the Chaldean; in praise of the Pope of Rome [8, p.63].

Like most other tūrgāmās, the text under discussion is composed in twelve syllabic metres, has an alphabetic acrostic and a common end-rhyme. Even the initial words Oh, ... who believe in ... [2, p.173-174] - usual for this highly standardized poetic genre are present here:

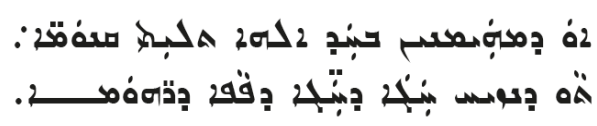

Oh, you who believe in one God, three Persons,

Come to celebrate a laud for the Pope of Rome! (see the Appendix, verse 1).

Poems in this format were standardized and collected in a general "Book of the tūrgāmās". In a similar way, unified and standardized were other kinds of East Syriac litur-

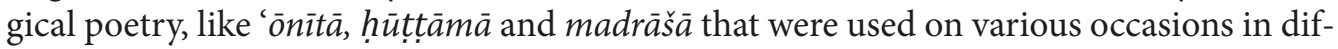
ferent moments of the liturgy [2, p. 159-181; on the 'ónitta genre see: 13]. Like most of the above mentioned liturgical poetry collections, "Book of the türgāmās" is believed to have appeared in the period of so-called Syriac Renaissance. This term has been lately applied to the revival of the Syriac literature in the $11^{\text {th }}-14^{\text {th }}$ centuries, which mostly coincided with the defeat of the Abbasids by the Mongols, and the founding a new Mongol dynasty in Iraq and Western Iran after the capture of Baghdad in 1258. This period in development 
of the Syriac literature for long had attracted little scholarly interest but has become one of the most booming directions in the field over the last decade [for instance, see: 13-21]. As far as the Ilkhans (Hulaguids) were concerned, the new dynasts were tolerant of religious minorities, and their wives were even informed members of the East Syriac (Nestorian) Church. Christian hierarchs and literati obtained access to the Royal court, and even lead Church liturgies in which monarchs and their families took part [20, p.347]. It has been pointed out in recent years that such a change in the political situation resulted in a change in the character of contemporary literature that was then compelled to address new challenges, namely participating in the life of the court. It is in this period that the traditional forms of the Syriac poetry were much transformed, using the achievements of IslamoArabic and Persian poetry in both technique and subject-matter. These intensive experiments resulted in an original synthesis that led, in turn, to a new heyday of this literature and the appearance of a number of genuine masterpieces [for instance, see: 22]. Thus, such forms as quatrains $\left(r u b \bar{a}^{-} \bar{i}\right)$, ghazals and qasydas were borrowed and adapted for the Syriac Christian literary tradition, and moreover, all these kinds of production still bore their traditional genre names, like sōghìtā, mèmrā, tūrgàmā. Some of such poems had lyrical or mystical contents. It is in that period that odes in praise of different contemporaries, such as monarchs, literati or Church Hierarchs were first composed in Syriac [e.g., see: 19; 21].

The nucleus of "Book of the tūrgāmās" is ascribed to "Abdīšō' bar Brīkhā (died 1318) [2, p. 173]. This hierarch was an outstanding East Syrian literate and polymath whose death, according Herman Teule, the leading expert in the literature of this period, marks the end of the Syriac Renaissance [23, p. 1-31]. The corpus includes 33 poems to be performed at liturgy before the Gospel readings of the dominical feasts, Lent or some other festivals. Later on, more tūrgāmās for each Sunday service were added [2, p. 173]. The outstanding poet seems to have been the one to set the metrical and poetic standards for the whole of this genre which was extended by later türgäma collections at the hands of others [17]. Among these are such outstanding poets as Israel of Alqosh (active between 1575 and 1630), and the namesake of the above mentioned author of the corpus, namely, 'Abdišso' of Gazarta, whose poetic production is discussed in the present paper. He composed a few tūrgāmās, the most popular of which is the that on Mār Qūriaqūs (St. Cyriacus) that has a notably large number of Greek loanwords [2, p. 173, 175]. This poem has been preserved in dozens of manuscripts, including the above mentioned BNF Syr. 434 (fol. 203r-204r) [12, p. 183], where it is present alongside the türgāma on the Pope by the same author.

Having chosen the türgāma form for a panegyric presented to the Pope, the author and the hierarch of the Chaldean Church was apparently trying to demonstrate that the piece in question was supposed to be read in all the numerous East Syriac churches that were under his jurisdiction. It is well-known that 'Abdišóc IV claimed his supremacy over numerous Syriac dioceses as far as in India, a see which was never approved by Rome [3, p.414]. Nevertheless, judging from an extremely small number of the available manuscript copies, one may doubt if the poem was really used at liturgy. Normally, hymnological texts, just like the one on Mār Qūrīaqūs, were most intensively transmitted and copied $^{3}$. Thus, the poem was most likely a pure panegyric in a way, traditional for Near East, when a poet presented an ode to a monarch, official or any other patron.

${ }^{3}$ For instance, the Wardā hymnological collection that is preserved in dozens of copies [more detailed, see: 13]. 
The poem is constructed as a suffrage addressed to Christ, which is very typical for the genre. The Pope is represented as a mediator between God and the Christians, and the text is designed as a prayer to God about him, asking to help the Pope in all his activities in protecting the Church.

The imagery used in the ode is characteristic for such poems, where all possible qualities of the addressee are described and praised. The Pope is shown as a person that has both spiritual and temporal power. That is why he is compared to a monarch (see below, verses 21-23). He is certainly also described as a pontifex, whose sanctity and prayers are to protect the faithful (see below, verses 37-38), whose legitimate descendants the Popes are claimed to be. Additionally, such qualities as possessing the Church's riches are also referred to, since he is called a custodian of Christ's treasury (see the Appendix, verses 17-18).

Some of the verses seem to allude to the contemporary political situation. The Pope is represented as a warrior against an evil, which could be associated with the Ottoman Empire that was generally considered an oppressor of Christians.

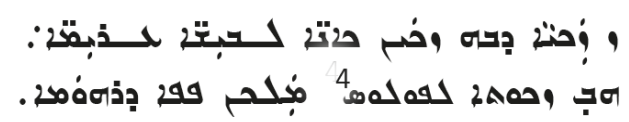

Zayn: Victorious one, by whom the righteous defeat the treacherous evil,

Grant victory to Paul ${ }^{5}$, our king, the Pope of Rome! (verses 13-14)

It is known that 'Abdīšo's predecessor Yōḥannān Sūlāqā himself was complaining about such oppressions during his sojourn in Rome [3, p.417; 5, p.214]. On the other hand, it could be any rival of the Catholic Church, including the Protestantism that had emerged right at that time, namely, in the $16^{\text {th }}$ century.

\section{Short verses devoted to Popes}

The short poems devoted to the Popes that are ascribed to 'Abdīšóc of Gazarta seem to have enjoyed much wider circulation. They are contained in at least three manuscripts that are used in the present study. They all belong to the library of the Chaldean Cathedral in Mardin (CCM), that has been first catalogued by Addai Scher in the early $20^{\text {th }}$ century [24], then recently digitized by the HMML project (Hill Museum and Manuscript Library, Minnesota), and now available online on its site in the library's entirety (with the prefix CCM used before the source/shelf number of the manuscripts) [25]. This is the largest and most important manuscript collection of the Chaldean Church that has survived up to the present, although it has undergone many changes since the time when it was first catalogued [26, p. 84; 21, p. 187].

The earliest and most important among the manuscripts that represent the poems under discussion is CCM 00398 ${ }^{6}$, written in $1583 \mathrm{CE}$, and containing hundreds of short poems most of which are ascribed to 'Abdišō' of Gazarta, thus being a key re-

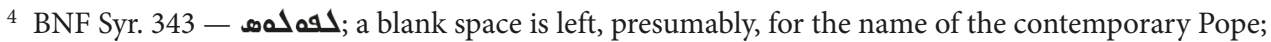
[8] +

${ }^{5}$ Following the Synodalia text [8].

${ }^{6}$ Formerly, in the Diyarbakir Chaldean collection, shelf-mark: Diyarbakir 95 [See: 27, S. 95]. URL online, HMML permanent link: https://w3id.org/vhmml/readingRoom/view/132517. 
source for studying his poetic legacy. To the best of my knowledge, Heleen Murre-van den Berg, the leading expert in the Syriac tradition of the Ottoman period, is presently conducting a detailed research on this manuscript that still remains unresearched and unpublished ${ }^{7}$.

The other two manuscripts belong to a much later period: CCM 00012, Macomber 81.3 of $1705-1719 \mathrm{CE}^{8}$, and CCM 00402 of the $16-17^{\text {th }}$ centuries (?) ${ }^{9}$, of which the first one contains all the poems under discussion, and the second only the last one (see below, poem 4). They only contain some of the poems under discussion. The problem is that in most manuscripts, like in these two, such small pieces are placed either between larger ones or on flyleaves. That is why they are usually not mentioned at cataloguing, and to find them one needs to scroll through all the manuscripts. For this reason, the complete number of the manuscripts containing them is unknown to me, though one can assume that they may be present in many more copies than the three thus far discovered. Consequently, it seems likely that, unlike the tūrgāman on the Pope discussed above, they were rather popular.

The poems found in CCM 00398 and ascribed to 'Abdišóc of Gazarta (see below, poems 1, 2, 3) may be attributed to him with a large degree of certainty, since it is the oldest and most representative collection of his verses. Besides, they are found in other, later manuscripts, where they are ascribed to the same author. The last poem (see below, poem 4) is found only in the later CCM 00012 and CCM 00402, which makes its attribution rather dubious.

All these short poems except one (see below, poems 1, 2, 4) are composed in the twelve-syllable meter and have a common end rhyme. Most of them consist of two syllable feet that are separated with a colon sign, each line containing six colons. In two of the pieces (see below, poems 1,4) that have six lines, the text may be read vertically or horizontally, so that the sequence of the feet remains the same. Moreover, these two poems are designed in a way that they may be read horizontally from top to bottom or from bottom to top, and vertically left to right or right to left so that the text would still preserve its sense. Thus, they represent a kind of palindrome. The first of them has the name Pius written each time above the word مسم (pure) in red ink in CCM 00012 in such a way that the poetic meter remains correct. This addition seems to be written in the same hand as the main text. Obviously, the piece is associated with the name of Pope Pius, to whom the poem could be possibly dedicated. It might have been either Pius IV (1559-1565) or Pius V (1566-1572), whose pontificate coincided with the patriarchate of 'Abdīšč IV. Most likely, it is Pius IV, who convened the Council of Trent in 1562, and whom the Syriac patriarch met in person.

It is worth mentioning that a few six-line palindrome poems of the same kind are written on the flyleaves of the manuscript CCM 00113 (fol.122v-123r), dated 1553 AD [27, p. 354; 18, p. 189-190], where they are ascribed to Khāmīs, the famous East Syriac poet of the late $13^{\text {th }}$ century [14-16]. Thus, this poetic technique too is associated with the period of the Syriac Renaissance.

The third poem (see below, poem 3) has a strophic structure that consists of three stanzas. Typically for the late Syriac poetry, they have 4 seven-syllable lines each. It is

7 Based on personal correspondence.

8 Available online, HMML permanent link: https://w3id.org/vhmml/readingRoom/view/132214.

9 Available online, HMML permanent link: https://w3id.org/vhmml/readingRoom/view/132521. 
dedicated to Pope named Julius, as mentioned in the text (see below, poem 3, stanza 2). Apparently, Julius of the new, Chaldean Church, the visit of Yōhannān Sūlāqā to Rome, the death of the latter, and ascending of 'Abdǐšóc IV to patriarchate.

It is quite possible that this poet and a Church prelate used to address a panegyric to each new Pope who had ascended pontificate. That seems very likely, given the important role of poetry in the Syriac tradition of the period, and an extreme prolificacy, in particular, in short poems.

In two poems, the Popes are represented as descendants of the apostles Peter and Paul (poem 3, stanza 3 and poem 4, verses 5, 6), which is quite typical for Catholic ecclesiology.

Four more six-syllable poems of the same type, i.e., those that permit being read in all possible directions, are found in Syriac, and in the Latin translation, in the same printed Synodalia edited by Pietro Strozzi in 1617 [8, p. 58]. They are not ascribed to 'Abdišš of Gazarta, and nor are they contained in any of the manuscripts of his works known to me. Thus, there exists no reason to attribute them to him. The third one, the only one of them mentioning the name of the Pope, namely, Paul, may possibly refer to Paul V (1605-1621) rather than to Paul IV (1555-1559), and therefore it could be a text contemporary with the main contents of the book that was composed in the early $17^{\text {th }}$ century. The remaining three could be later productions, as well. It is not surprising that poems of such type could appear later for different occasions and thus be mentioning new Popes. A number of various anonymous poems of this type are contained in different manuscripts, and thus one may say that the works by 'Abdišōo of Gazarta discussed and published here did form a poetic canon for the later generations of the Chaldean Church.

$\underline{\text { Text and translation }}$

CCM 00398, fol. 258v

CCM 00012, Macomber 81.3, fol. 291v-292r

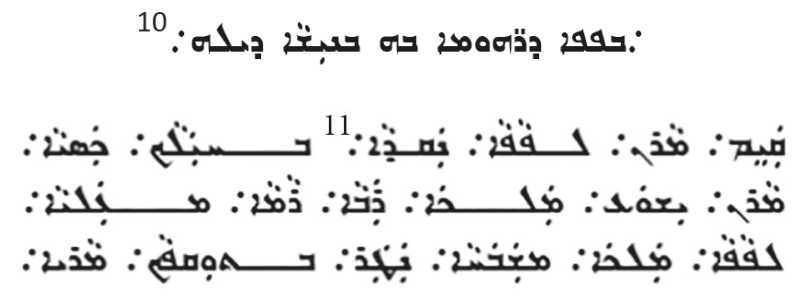

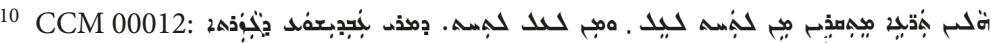

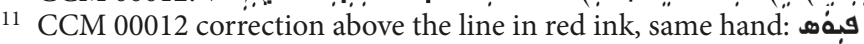




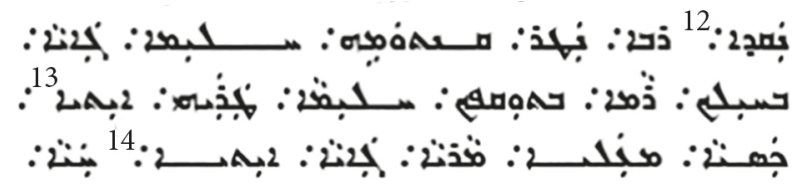

\section{On the Pope of Rome, on the same object; by the same one ${ }^{15}$}

Support, our Lord, the pure ${ }^{16}$ Pope, with your hidden power!

Our Lord, Jesus, the great sublime King,

guard the Pope, the glorious king, with your support, oh Lord!

Pure ${ }^{17}$, great, guard the right [and] glorious person

with your high power, your right support, guard him, oh the ever-existing One,

Concealed, sublime, Lord, the glorious [and] living!

CCM 00398, fol. 258v

CCM 00012, Macomber 81.3, fol. 292r

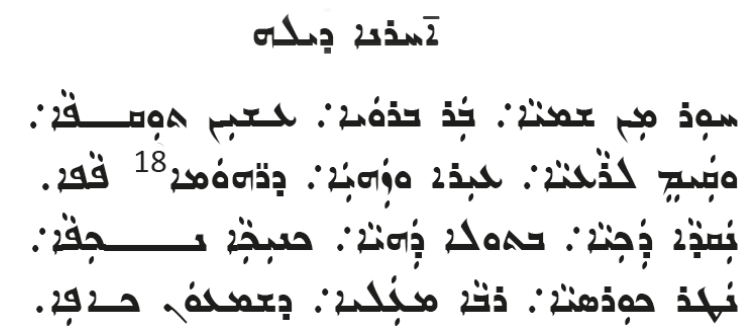

Another, by the same one ${ }^{19}$

Look from the sky, Son of the Creator, firm in the foundation, and support the pastor, vigilant and true, the Pope of Rome ${ }^{20}$, noble, pure, celibate, splendid, humble, chaste! Guard the great, elevated throne of Simon Kipha! ${ }^{21}$

CCM 00398, fol. 259r

CCM 00012, fol. 292r

وبفه : 12 CCM 00012 correction above the line in red ink, same hand

13 CCM 00012 (5iّ2

14 CCM 00012 ספב2

15 CCM 00012: And these verses are read upward and downward; by 'Abdī̌̌ǒ of Gazarta.

16 CCM 00012: correction above the line in red ink, same hand: Pius.

17 CCM 00012: correction above the line in red ink, same hand: Pius.

18 CCM 00012 correction above the line in red ink, same hand: وبفه

19 i.e. by 'Abdišǒ of Gazarta, since the previous several poems in this manuscript are ascribed to him.

${ }^{20}$ CCM 00012 correction above the line in red ink, same hand: Pius.

${ }^{21}$ Aramaic for "stone"; i.e. an original Aramaic version of the Apostle Peter's name (see Jn 1:42). 


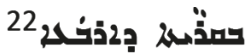

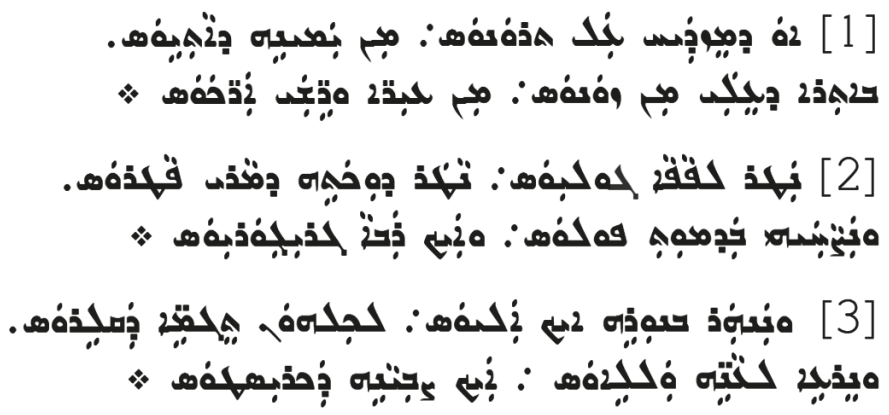

\section{Arranged in quatrain}

[1] Oh, who sits enthroned

On the right hand of God

In the place that is more elevated than firmament, than angels and heads of the Powers,

[2] preserve Pope Julius ${ }^{23}$, the locum tenens of Mār Pāțrōs ${ }^{24}$, make him illustrious like Paul, or like the great Gregory.

[3] And he will shine with his light like Elijah, Among all the ranks of the Church clergy. And he will graze his herd and people according to Christ's will.

CCM 00012, Macomber 81.3, 1705-1719 CE, fol. 291v

CCM 00402, 16-17th cent. (?), fol. 146v

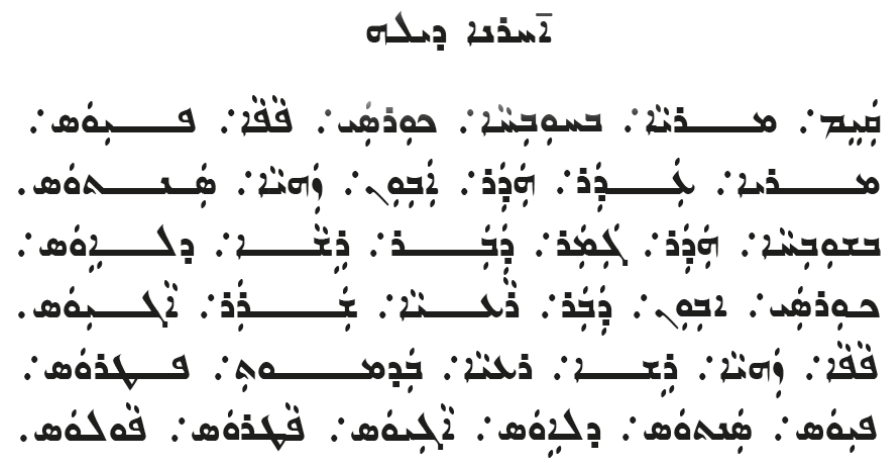

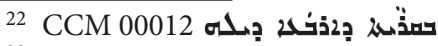

23 Apparently, Julius III (7 February 1550 - 29 March 1555).

24 i.e. of Apostle Peter. 


\section{Another, by the same one ${ }^{25}$}

Support, Lord, with Your glory the throne of Pope Pius,

Lord help, illuminate our magnificent, saint lord!

Illuminate, perfect, lead with your glory the head of the people.

Settle the throne of our lord, lead and approve the saint pastor,

magnificent Pope, head pastor like Peter,

Saint Pius of holy Leo ${ }^{26}$, Peter, Paul!

\section{Conclusion}

The versified texts discussed here constitute a result of a long evolution of Syriac poetry and its interaction with poetry of Islam. They were much influenced by the poetic tradition of the Syriac Renaissance $\left(11^{\text {th }}-14^{\text {th }}\right.$ centuries), but at the same time reflect a new situation that appeared in the mid $-16^{\text {th }}$ century, when the East Syriac Church sought the protection of the Roman Catholic church. At that period, new motives appeared in versified texts, such as praising the popes over local rulers, for instance, whose support and approval the new Chaldean Church hierarchs sought. That is how the new, Chaldean (East Syriac Uniate) poetic tradition emerged. The pieces discussed in the present paper represent its early samples, and exemplify the very beginning of the tradition that was connected with the name of 'Adbǐšó of Gazarta, the second patriarch of the new Church, an outstanding literate, whose legacy is much understudied. One should also note that the Syriac Church hierarchs were deeply involved in poetic activities since the Mongol period. Such outstanding poets and Church prelates as Bar 'Ebroyo (1226-1286) and 'Adbīšō' bar Brikhā (died 1318) defined the development of the poetic style for centuries. In the Ottoman period this tradition was continued, when poetry was considered by the Church hierarchs and poets like 'Adbī̌sō' of Gazarta as a means for keeping contacts with the Roman Church, and a way of venerating their new protectors.

\section{The Appendix}

An ode dedicated to Paul IV

Text

BNF Syr. 434, fol. 204r-205r

[8, p. 62-67].

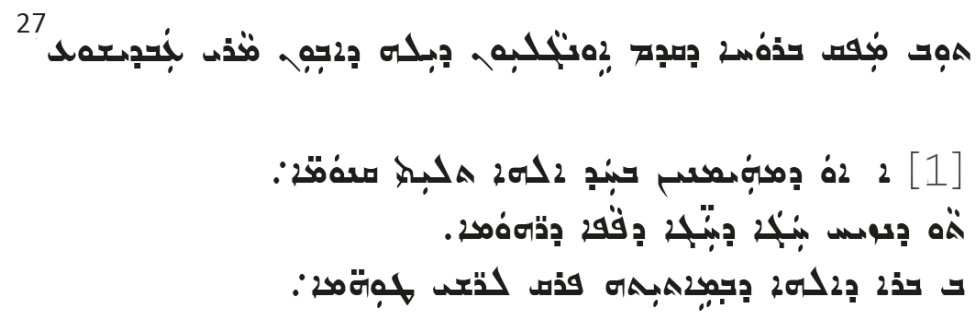

25 i.e. by 'Abdī̌šc of Gazarta, since the previous several poems in this manuscript are ascribed to him.

26 Apparently, Pope Leo the Great (ca. 400 - 10 November 461).

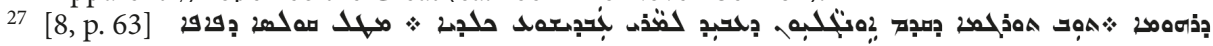




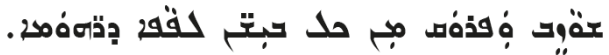

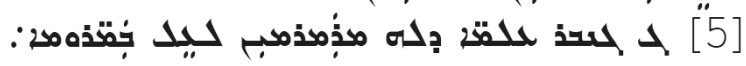
ذُمذّح حبذّمسه

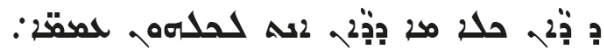

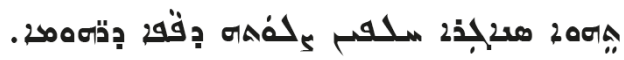
o

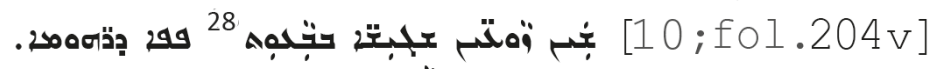

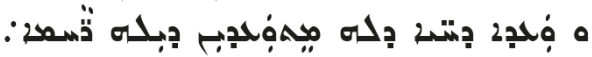

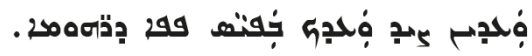

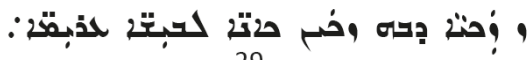

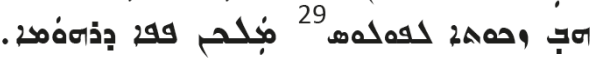

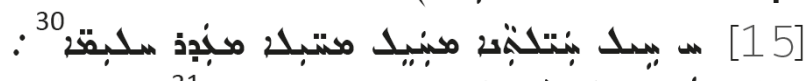

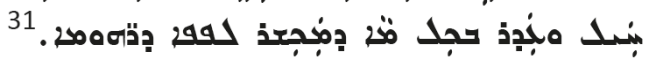

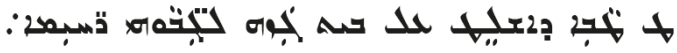

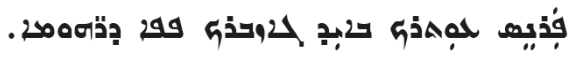

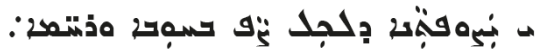

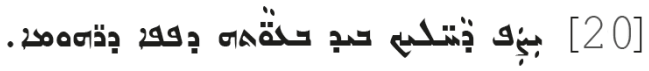

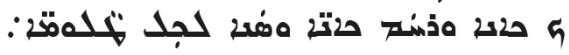

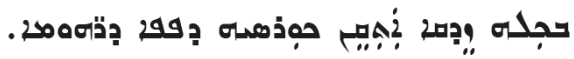

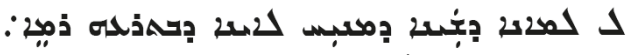

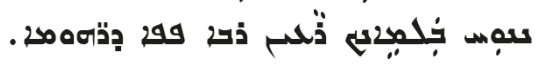

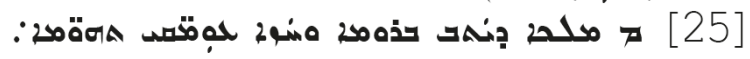

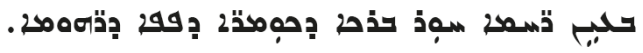

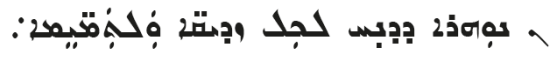

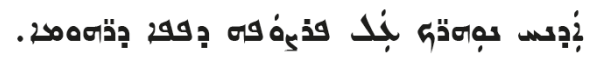

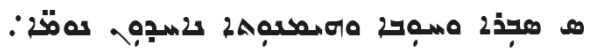
30 ifol.205r]

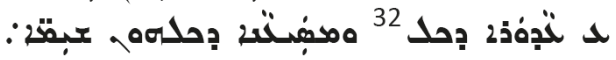
9

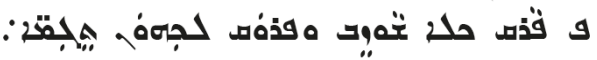

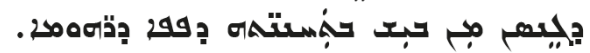

28 בتخِف [21]

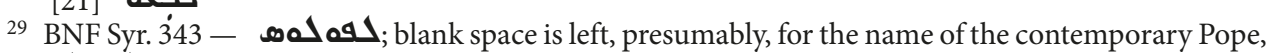
$[8]+$ o.

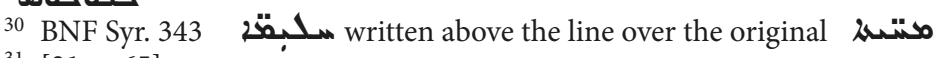

31 [21, p. 65].

32 [21, p. 67]. 


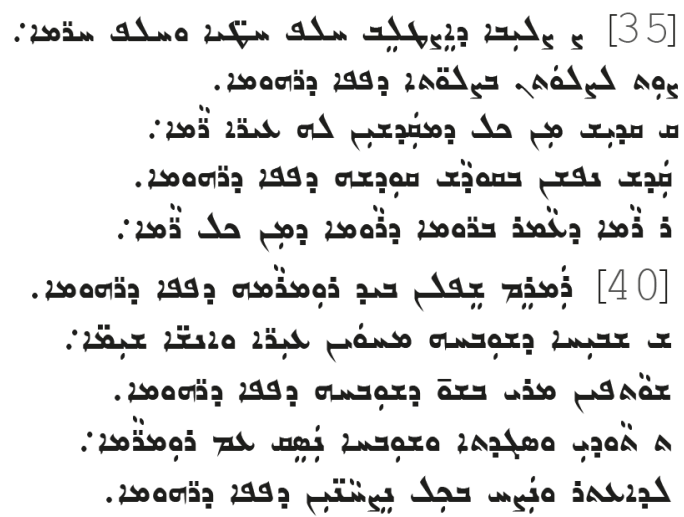

\section{Translation}

[fol. 204r] Also exalted in spirit, before the Gospels; by Abūn Mār 'Abdīšōo'33

[1] 'Álep: Oh, you who believe in one God, three Persons, Come to celebrate a laud for the Pope of Rome! Be tet: Son of God, who saved the heads of the families by His coming, protect and save from all troubles the Pope of Rome!

[5] Gämal: Hero of the worlds who is elevated sublime in the heights, elevate and raise the horn ${ }^{34}$ of the Pope of Rome!

Dālat: Judge of everything that will judge all people, be our solicitor through the prayer of the Pope of Rome!

$H \bar{e}$ : Envoy for us, by whom both worlds were pacified, [10; fol. 204v] pacify our disturbed motions by the rogation of the Pope of Rome! Waw: Promise of the life that is promised His friends, accompany us to your promised place by the supplication of the Pope of Rome! Zayn: Victorious one, by whom the righteous defeat the treacherous evil, grant victory to Paul ${ }^{35}$, our king, the Pope of Rome!

[15] Het t: Strength of the strong strengthening the weak, helping the right, strengthen and help in anything is suited to the Pope of Rome!

Tiet: Good one who authorized His beloved and chosen ones over his treasury, distribute your wealth with the hands of Your custodian, the Pope of Rome! Yōd: O overseer that oversees everything with love and mercy, [20] oversee the fearing of You by the rogation of the Pope of Rome! $K \bar{a} \bar{p}$ : Just and the Lover of the just ones, and hater of any oppressors, support by all righteousness the throne the Pope of Rome!

Lämad: Harbour of rest that consoles everyone who sets out for Your gate,

33 [8]: Then a tūrgāmā before the Gospels, composed by Mār 'Abdī̌ōo the Chaldean; in praise of the Pope of Rome.

34 BNF Syr. 434: the name Paul is omitted, and some blank space is left.

35 Following the Synodalia text [8]. 
let be consoled in your harbour our great pastor, the Pope of Rome!

[25] Mim: King that dwells in the height and watches depths of the abyss, watch with the eye of Your mercy the great pontiff, the Pope of Rome!

$N \bar{u} n$ : Light that shines in all the righteous and perfect,

make Your light shine on the personality of the Pope of Rome!

Semkat: May hope and love and faith be propagated

[30; fol. 205r] in our soul through the petitions of the Pope of Rome!

' $\bar{E}$ : Helper and assister of all the wretched,

be our assistance through the implorations of the Pope of Rome!

$P \bar{e}$ : Saviour of everyone, keep and save all the classes

of our [human] kind from the evil by the supplications the Pope of Rome!

[35] Sā $\underline{\text { dee: The Sign of Cross }}{ }^{36}$ that was crucified instead of the sinners and evildoers, attend our prayer by the prayers of the Pope of Rome!

Qōp: The holiest of all, who is sanctified by the sublime angels,

sanctify our soul by the utmost sanctity of the Pope of Rome!

Rēs: The high one who dwells in the height of heights, higher than everything,

[40] heighten our lowliess through the exaltation of the Pope of Rome!

Šin: The glorious one, whose glory in manifested by angels and feeble people alike, accompany us, Lord, in glorification of the glory of the Pope of Rome!

Taw: Let us render confession, adoration, glory and exaltation

to Him who has enriched and made glorious with any triumphs the Pope of Rome!

\section{References}

1. Wilmshurst D. The Eccesiastical Organisation of the Church of the East, 1318-1913, CSCO, Subsidia 104. Louvain, Peeters, 2000. 855 p.

2. Murre-van den Berg H. L. Scribes and Scriptures. The Church of the East in the Eastern Ottoman Provinces (1500-1850), Eastern Christian Studies 21, Leuven, Peeters, 2015. 399 p.

3. Baskins C. Popes, patriarchs, and print: representing Chaldeans in Renaissance Rome. Renaissance Studies, 2013, vol. 28, no. 3, pp. 405-425.

4. Murre-van den Berg H. L. The Patriarchs of the Church of the East from the Fifteenth to Eighteenth Centuries'. Hugoye: Journal of Syriac Studies, 1999, no. 2:2, pp. 235-264.

5. Vosté J. M. Mar Iohannan Soulaqa, premier Patriarche des Chaldéens, martyr de l'union avec Rome (†1555). Angelicum, 1931, no. 8, pp. 187-234.

6. Baumstark A. Geschichte der syrischen Literatur, mit Ausschluss der christlich-palästinensischen Texte. Bonn, A. Marcus und E. Weber Publ., 1922. 378 S.

7. Giamil S. Genuinae relationes inter sedem apostolicam et assyriorum orientalium seu chaldaeorum ecclesiam nunc major ex parte primum editae historicisque adnot. Illustratae. Rome, Loescher, 1902.648 p.

8. Strozzi P. Synodalia Chaldaeorvm, videlicet epistola synodica Eliae patriarchae Babylonis, \& archiepiscoporum eius obendientiae: ad D. Pavlvm Papam V. Romae, Bartholomaeus Zannetti, 1617. 86 p.

9. Bedjan P., ed. Manuel de piété, ou Livre de prières, de méditations et des offices, en langue chaldéenne. Paris: Maisonneuve et Ch. Leclerc, 1893.

10. Borbone P. G. The Chaldean Business: The Beginnings of East Syriac Typography and the Profession of Faith of Patriarch Elias (Vat. Ar. 83, ff. 117-126). Miscellanea Bibliothecae Apostolicae Vaticanae XX. Studi e Testi, 2014, vol. 484, pp. 211-258.

11. Coakley J. F. The Typography of Syriac: A Historical Catalogue of Printing Types, 1537-1958. New Castle, DE: Oak Knoll Press. London, British Library, 2006. 272 p.

12. Briquel-Chatonnet F. Manuscrits syriaques de la Bibliothèque nationale de France (n. ${ }^{\circ} 356-435$, entrés depuis 1911), de la Bibliothèque Méjanes d’Aix-en-Provence, de la Bibliothèque municipale de Lyon et de la Bibliothèque nationale et universitaire de Strasbourg. Paris, 1997. 260 p.

\footnotetext{
${ }^{36}$ Or: the Crucified One.
} 
13. Pritula A. The Wardā: An East Syriac Hymnological Collection. Study and Critical Edition. Göttinger Orientforschungen I. Reihe: Syriaca. Martin Tamcke (ed.). Bd. 47, Wiesbaden: Harrassowitz Verlag, 2015. $559 \mathrm{p}$.

14. Taylor D. G. K. Your Sweet Saliva is the Living Wine: Drink, Desire, and Devotion in the Syriac Wine Songs of Khāmīs Bar Qardāhē. The Syriac Renaissance. Eds Teule H., Tauwinkl C. F, et al. Eastern Christian Studies. Leuven, Paris, Walpole, MA, Peeters, 2010, pp. 31-52.

15. Mengozzi A. Persische Lyrik in syrischem Gewand: Vierzeiler aus dem Buch des Khamis bar Qardahe (Ende 13. Jh.). Geschichte, Theologie und Kultur des syrischen Christentums: Beiträge zum 7. Deutschen Syrologie-Symposium in Göttingen, Dezember 2011. Tamcke M. and Grebenstein S. (eds.). Göttinger Orient-forschungen, I. Reihe: Syriaca 46. Wiesbaden, Harrassowitz Verlag, 2014, S. 155-176.

16. Mengozzi A. Quatrains on Love by Khamis bar Qardahe: Syriac Sufi Poetry. Christsein in der islamischen Welt: Festschrift für Martin Tamcke zum 60. Geburtstag. Griffith S. H. and Grebenstein S. (eds.). Wiesbaden: Harrassowitz Verlag, 2015, pp. 331-344.

17. Mengozzi A., Pastore D. The Late East-Syriac Genre of the Turgāmā: Forms, Function, Vitality in the Liturgy. Khristianskii Vostok, 2017, vol. 8 (XIV), pp. 171-187.

18. Pritula A. Khamis bar Qardahe (kon. XIII v.) i arbelskiy literaturniy krug [Khamis Bar Cardah (late XIII century) and the Arbel literary circle.]. Khristianskii Vostok, 2012, vol. 6 (12), pp. 216-243. (In Russian)

19. Pritula A. Zwei Gedichte des Huāmīs bar Qardāḥẹ: Ein Hochgesang zu Ehren von Bar 'Ebrōyō und ein Wein-Gedicht für die Khan-Residenz / Geschichte, Theologie und Kultur des syrischen Christentums: Beiträge zum 7. Deutschen Syrologie-Symposium in Göttingen, Dezember 2011. Tamcke M. and Grebenstein S. (eds.). Göttinger Orientforschungen, I. Reihe: Syriaca 46. Wiesbaden: Harrassowitz Verlag, 2014, pp. 315-328.

20. Pritula A. Syroturcica: A Bilingual Poem from the Mongol Time. Christsein in der islamischen Welt: Festschrift für Martin Tamcke zum 60. Geburtstag. Eds Griffith S. H. and Grebenstein S. Wiesbaden, Harrassowitz Verlag, 2015, pp. 345-357.

21. Pritula A. One More Unknown Khāmīs' Ode in Honor of Bar 'Ebrōyō. Khristianskii Vostok, 2017, vol. 8 (XIV), pp. 187-195.

22. Hōššbbā Š. İ. (ed.). Khāmīs bar Qardāḥē. Mēmrē w-mūšhātā. Dahok, Nuhra, 2002. 346 p.

23. Teule H. The Syriac Renaissance. The Syriac Renaissance. Eds Teule H., Tauwinkl C. F., et al. Eastern Christian Studies. Leuven, Paris, Walpole, MA, Peeters, 2010, pp. 1-31.

24. Scher A. Notice des mss. syriaques et arabes conservés dans la bibliothèque de lévêché chaldéen de Mardin. Revue des bibliothèques, 1908, no. 18, pp. 64-95.

25. Stewart C. "An Update on the Digitization and Cataloging Work of the Hill Museum and Manuscript Library (HMML). Khristianskii Vostok, 2017, vol. 8 (XIV), pp. 153-171.

26. Kessel M. G. Manuscript Collection of the Syrian Orthodox Church Meryemana. Diyarbakır: A Preliminary Survey, in Manuscripta Syriaca. Des sources de première main. Eds F. Briquel-Chatonnet, M. Debié. Cahiers d'études syriaques 4. Paris, 2015, pp. 79-123.

27. Scher A. Notice sur les manuscrits syriaques et arabes conservés à l'archevêché chaldéen de Diar-békir." Journal asiatique, 1907, no. 10, pp. 331-362, 385-431.

Received: April 17, 2018 Accepted: June 15, 2018

Author's information:

Anton D.Pritula — PhD in Philology; pritulanna@googlemail.com

\title{
'Авдишо' Газартский, первый литератор Халдейской церкви: стихотворения, посвященные римским папам
}

\author{
А. Д. Притула \\ Государственный Эрмитаж, \\ Российская Федерация, 190000, Санкт-Петербург, Дворцовая наб., 34
}

Для цитирования: Pritula A. D. 'Abdī̌so' of Gazarta, the first literate of the Chaldean Church: Poems dedicated to the Popes of Rome // Вестник Санкт-Петербургского университета. Востоковедение и африканистика. 2018. Т. 10. Вып. 3. С. 374-391. https://doi.org/10.21638/spbu13.2018.307 
Статья посвящена сирийским поэтическим текстам времен Османской империи, связанным с историей Халдейской (Восточносирийской униатской) церкви. Они были сочинены 'Авдишо' Газартским, вторым патриархом новой Церкви (1555-1570) и выдающимся литератором, наследие которого остается в значительной степени неизученным. Произведения, рассматриваемые в статье, представляют собой наиболее ранние образцы, восходящие к самому началу литературной традиции, связанной с именем 'Авдишо' Газартского. Они посвящены римским папам, с которыми молодая Халдейская церковь установила интенсивные контакты и главенство которых признавала. Хотя эти короткие тексты, сочиненные по различным случаям, никогда не были объектом детального исследования, они содержат важную информацию как по истории сирийской литературы, так и по истории христианских церквей в этом регионе.

Ключевые слова: сирийская поэзия, христианские общины в Османской империи, оды о римских папах, рукописная передача.

Контактная информация:

Притула Антон Дмитриевич - канд. филол. наук; pritulanna@googlemail.com 